\title{
Effect of Edutainment Instructional Approach on Students' Academic Achievement and Retention in Building Technology in Technical Colleges
}

\author{
T. I. Eze ${ }^{1}$, Magnus G. Ekon ${ }^{1} \&$ Jacinta Ifeoma Obidile ${ }^{1}$ \\ ${ }^{1}$ Department of Technology and Vocational Education, NnamdiAzikiwe University, Awka, Nigeria \\ Correspondence: Dr. Jacinta Ifeoma Obidile, Department of Technology and Vocational Education, Nnamdi Azikiwe \\ University, Awka, Nigeria.
}

Received: February 20, 2020

Accepted: March 26, 2020

Online Published: March 30, 2020

doi:10.5430/irhe.v5n1p34

URL: https://doi.org/10.5430/irhe.v5n1p34

\begin{abstract}
The teaching and learning of building technology in technical colleges seems to be characterised by poor academic achievement and retention of concepts. This called for the search for innovative teaching approaches like the edutainment instructional approach. The study was therefore conducted to determine the effect of edutainment instructional approach on students' academic achievement and retention in building technology in technical colleges. Two research questions guided the study and two null hypotheses were tested at 0.05 level of significance. The study adopted the quasi-experimental design in which there were pre-test and post-test in the experimental and control groups. The population of the study comprised all the 946 senior technical II (ST2) students offering building technology in the six public technical colleges in Akwa Ibom State. Purposive sampling technique was used to select four technical colleges in the study area. Three instrument namely: edutainment lesson plans, conventional lesson plans and building technology achievement test (BTAT) were used in the study. Three experts validated the instrument. Test-retest reliability of the instrument which yielded an index of 0.87 obtained using Pearson product moment correlation coefficient. The data collected for the study were analysed using the mean scores and standard deviation for answering the research questions while hypotheses were tested with the analysis of covariance (ANCOVA) at 0.05 level of significance. The study found that: the edutainment instructional approach enhanced students' academic achievement and retention in building technology more than the conventional lecture method. There was significant difference in the academic achievement and retention of students in building technology between the two groups. The significance was attributed to the experimental group which obtained a higher mean score in the post-test and retention test. It was recommended that: teachers of building technology in technical colleges in Akwa Ibom State should adopt edutainment instructional approach in the teaching of building technology courses in order to enhance students' academic achievement and retention in building technology.
\end{abstract}

Keywords: academic achievement, retention, edutainment instructional approach, building technology, technical colleges

\section{Introduction}

The advancement in computer technology which has led to the proliferation of various types of educational videos and other multimedia educational resources has considerably changed the way students prefer to learn in the 21st century classroom. Steffes and Duverger (2012) posited that students today expect to be entertained as well as being educated. This situation has posed serious instructional challenges to teachers. Accordingly, teachers have to be in constant search of teaching approaches that would improve their practice, encourage learners to participate actively in the learning process and adapt more perfectly to their peculiar classroom situations (Oviawe, Ezeji and Uwameiye, 2015). Hwa (2009) suggested that the use of a teaching approach built on the educational values of entertainment and fun could be an appropriate way to improve learning. The author also noted that one of the instructional approaches that heavily utilised the educational values of entertainment and fun and which could be efficacious in increasing achievement, retention as well as stimulating students' interest and attitude towards science-based subjects is edutainment.

Edutainment is an instructional strategy that involves teaching through a medium that both educates and entertains at 
the same time (Davies, 2013). Adieze (2016) viewed edutainment as an instructional strategy that combines education and entertainment to teach humans about a specific subject and skill through an interactive process that emphasizes problem-solving and interaction. According to Heiden (2007), edutainment incorporates a variety of entertainment such as storytelling, toys, multimedia, internet sites, music, films, videos and computer games as well as television programmes in order to exhilarate in addition to educating. Simply put, edutainment is an instructional strategy which typically seeks to instruct its audience by embedding lessons in familiar forms of entertainment such as games, videos, music, television programmes, computer and other multimedia resources in such a way that it provides information that are both educative and entertaining at the same time (Pakprod and Wannapiroon, 2015).In the context of this paper, edutainment is viewed as a teacher-student interactive method of teaching that integrate some elements of fun, humour and entertainment in the lesson presentation in order to entertain and educate the students simultaneously as well as motivate, attract and sustain their attention so as to enhance their academic achievement.

The literature has identified several advantages of edutainment. For instance, Berk (2008) pointed out that using background music has many educational values such as grabbing students' attention; focusing students' concentration on the lesson; generating interest in the class; creating a sense of anticipation; establishing a positive classroom atmosphere and relaxing students for an effective learning exercise. Edutainment instructional approach could also enhance students' attention and interest in the learning process and thereby lead to improved academic achievement.

In view of the importance of Building Technology in fostering national development, the need for improving students' academic achievement in the subject becomes very critical. Available statistics indicate that students' academic achievement in Building Technology has been consistently poor in recent years as the Chief examiners' reports of the National Business and Technical Examination Board (NABTEB) indicated (NABTEB, 2011, 2012a, 2012b).The Chief Examiners Reports as well as several studies such as Oviawe (2010), Usoro and Essien (2012), Odu (2012), Oviawe, Ezeji and Uwameiye (2015) and Oviawe, Ezeji and Uwameiye (2016) have attributed the students' poor performance in Building Technology to poor teaching strategies. Eze, Ezenwafor and Obidile (2016) lamented that it is worrisome to note that some teachers do not always employ student-centred methods due to lack of time hence they resort to the use of lecture method which is a teacher-centred teaching method. This method often creates frustration and learning difficulties for students culminating in poor academic achievement. In addition, the teaching method does not allow the teacher to create enjoyment, humour or fun nor give students ample opportunities to participate actively in the learning process. Udofia (2008) noted that the absence of fun-related teaching techniques partly accounts for the apathy shown by many students towards technology subjects which culminate in their poor achievement in these subjects.

Studies have shown that the use of fun and entertainment-related teaching activities such as games (Fatokun, Egya and Uzoechi, 2016; Boyle, 2011; Karen, 2015); music (Berk, 2008); puzzle (Adedoja and Fakokunde, 2015; Keshta and Al-faleet, 2013); story telling (Abiola, 2014; Kotluk and Kocakaya, 2017) and multimedia (Surjomo, 2015; Umar, Idris, Audu, Arah, Yusuf and Beji, 2015) could improve students' academic achievement and retention considerably in many subjects.

However, despite the numerous documented research findings on the effectiveness of edutainment instructional approach in enhancing students' academic achievement and retention in other vocational subject areas such as Introductory Technology(Udofia, 2008) and Business Studies (Adieze, 2016), empirical studies are rare for its effectiveness in Building Technology in Technical Colleges. Moreover, the effects of gender and ability levels on students' academic achievement and retention in Building Technology when taught with edutainment instructional approach are inconclusive. Furthermore, the interaction effects of teaching method and gender on students' academic achievement and retention in Building Technology with edutainment instructional approach are equally indeterminate. The absence of research studies that address these issues therefore solicits for a study to answer the question: What are the effects of edutainment instructional approach on students' academic achievement and retention in Building Technology in Technical Colleges? The search for an answer to this question, using some selected Technical Colleges in Akwa Ibom State, forms the drive for this paper.

Specifically, this paper sought to determine:

(i) Differences in the mean achievement scores of students when taught Building Technology with edutainment instructional approach and when taught with the conventional lecture method;

(ii) Differences in the mean retention scores of students when taught Building Technology with edutainment instructional approach and when taught with the conventional lecture method. 


\subsection{Hypotheses}

The following null hypotheses were tested at 0.05 level of significant:

1. There is no significant difference between the post-test mean achievement scores of students taught Building Technology using edutainment instructional approach and those taught with conventional lecture method.

2. There is no significant difference between the mean retention scores of students taught building technology with the edutainment instructional approach and those taught with the conventional lecture method.

\section{Method}

The study used the quasi-experimental design in which there were pre-test and post-test in the experimental and control groups. To do this, intact classes (non- randomized groups) were used. According to Cohen, Manion and Morrison (2011) and Nworgu (2015), quasi-experimental pre-test - post-test non-equivalent group design should be adopted when it is not possible for the researcher to randomly sample the subjects and assign them to groups without disrupting the academic programmes of the schools involved in the study.

The study was conducted in Akwa Ibom State. There are six Technical Colleges in the state located at Ewet, Abak, IkotAkata, IkotUkoIka, Ikpa and Oron. The population of this study comprised all the 946 Senior Technical 11 (ST 2) students offering Building Technology in the six public Technical Colleges in Akwa Ibom state. The data was obtained for the 2017/2018 session from the State Technical Schools Board, Uyo. Senior Technical 11 (ST 2) students were chosen for this study because they have made a choice of their course/trade.

The sample for this study consisted of 160 students. They were selected through purposive sampling technique from four Technical Colleges in the study area based on the schools that offer Building Technology as well as those that have the teaching facilities. From the four schools selected, one intact class each was used giving a total of four intact classes. Each intact class contain an average of 40 students. The four intact classes, were randomly assigned to the experimental and control groups.

The instrument used was Building Technology Achievement Test (BTAT). The edutainment lesson plans constituted the treatment that was given to the experimental groups while the control groups were taught with the conventional lesson plans. The edutainment lesson plan incorporates the edutainment activities namely use of multi-media and puzzle. It should be emphasized that all the edutainment activities were interwoven in the lesson. In a nutshell, each edutainment lesson plan indicates, among others, the lesson topic, specific objectives, entry behaviour, instructional materials and the instructional procedure. The instructional procedures show details of the steps, content development, teacher's activities, the edutainment activities and students' activities.

The Building Technology Achievement Test (BTAT) consisted of 25 multiple choice items adapted from National Technical Certificate past questions organized by NABTEB. Each item has four options one of which is the correct answer while the other three are distracters. Each correct answer attracts four points. The 25 test items covered the six topics in the lesson plans. The items were used for the pre-test for the experimental and control groups, after which the items were reorganized and used for the post-test. After the post-test, the items in the instrument were again re-organized before administering them as delayed post-test or retention test for the experimental and control groups.

The Building Technology Achievement Test (BTAT) was already validated by the test developer, the National Business and Technical Examinations Board (NABTEB). The test (BTAT) has acceptable psychometric properties namely difficulty indices, discrimination indices and distractor indices, hence, it was considered valid to be used for this study.

The edutainment lesson plans and the conventional lesson plans were validated by three experts as follows: two from the Department of Vocational Education and one from Educational Foundations Unit, all in the Faculty of Education, NnamdiAzikiwe University, Awka. The experts were required to crosscheck the instruments to ensure that they cover the selected topics and that the edutainment activities are properly incorporated into the edutainment lesson plans. Their inputs led to the modifications which were reflected in the final draft of the instruments.

To determine the reliability coefficient of the Building Technology Achievement Test, the test was administered to 30 ST 2 students selected from Technical Colleges in Cross River State who have the same characteristics as those in the study area but were not part of the population. The tests were administered to them on two occasions within 14 days interval. Their scores of the tests were analysed using Pearson Product Moment Correlation Coefficient to 
determine the coefficient of stability of the instrument. A reliability index of 0.87 was obtained indicating that the instrument was reliable for use in the study.

\subsection{Experimental Procedure}

The researchers visited the schools and obtained permission from the school authority to conduct the study. The researchers introduced themselves to the teachers of Building Technology and appointed one of the teachers who is literate in computer and the use of multimedia systems in teaching as research assistant. The nature of the experiment was explained to the students who were taught by the regular class teachers using the normal school time-table so as to create the impression that the experiment was a continuity of regular class activities. One week briefing was organised for the teachers where they were briefed on how to use the lesson plans and how to administer the tests (pre-test, post-test and retention test).

The experimental group teachers were given detailed explanations on the techniques of edutainment. The edutainment lesson plans and how to incorporate the edutainment activities into the lessons as well as the general requirements of the research were also explained. Also, they were intimated on the general requirements of the research. At the end of the briefing, the researchers organized a small technical session for the participating teachers to ensure that they have mastered the edutainment technique.

The researchers, with the help of four research assistants, first subjected the two experimental and two control groups to a pre-testing exercise with the Building Technology Achievement Test (BTAT). This exercise provided baseline data that was used to compare subjects in both groups. The pre-test scores were also used to classify the students into three ability groups namely high, medium and low based on the criteria given by Betts and Shkolnik (2000) and Udoetuk (2007) as follows: High ability group (from 70\% and above); Medium ability group (50\% to 69\%) and Low ability group ( $1 \%$ to $49 \%)$.

Thereafter, the experimental group was subjected to the treatment with the edutainment lesson plans. The edutainment lesson plans incorporated edutainment activities namely use of video clips with multi-media television, illustrations to create fun and puzzles. These activities greatly created fun, excitement, students' active participation in their learning, group learning activities, practical hands-on activities and enhanced connectedness of the lesson to real-world situations.

The experimental group were taught six lessons with the edutainment lesson plans for two weeks while the control group were taught the same six lessons with the lecture method for the same length of time, using the conventional lesson plan. Each lesson lasted for 45 minutes. In the edutainment lesson, one-third of the time was devoted to teaching while the remaining time was devoted to practical activities with the edutainment instructional techniques. The experimental group teachers used multi-media which incorporated videos with background music and voice narration in the presentation of the lessons. This provided entertainment, fun, excitement and motivation in learning. The experimental group teachers also ensured that students were given puzzles for arousing their critical thinking/problem solving skills. The control group teachers taught the students using the usual instructional materials for normal lessons. The lessons were taught three times a week and the treatment lasted for two weeks as indicated in their weekly activities.

At the end of the treatment, a post-test was administered on both groups with the BTAT. The scores obtained by subjects in the experimental groups in both pre-test and post-test were recorded and compared with the scores obtained by those in the control groups in both tests to determine if there was any significant difference in the achievement of the two groups.

Two weeks after, the delayed post-test was administered on both groups as retention test. The scores were also recorded and compared in order to assess the extent of retention of the material learnt by the subjects in the two groups.

\subsection{Control of Extraneous Variables}

The following experimental precautions were put in place in order to control extraneous variables and thus enhanced the internal validity of the research.

i. Experimental Bias: To avoid any experimental bias, the regular class teachers in the participating schools were used to teach their own students in both the experimental and control groups. The researchers were therefore not directly involved in administering the research instruments so that the participating students would not know that they were being used for a study.

ii. Teacher Variability: Usually each teacher has an instructional pattern which could manifest when various 
teachers teach the students. In order to control this variability and hence ensure uniform teaching standard in the conduct of the research, the researchers personally prepared the edutainment and conventional lesson plans. In addition, it was ensured that the participating teachers have similar characteristics such as educational qualification, years of teaching experience and salary grade level. Moreover, the participating teachers were briefed but they were not allowed access to the test instruments until the time it was to be administered.

iii. Hawthorne Effect: Regular classroom teachers were used and the subjects in both groups were not informed that they were being involved in any research process. This was to enable them behave naturally and prevent them from acting in any manner that could influence the result of the research either negatively or positively. Moreover, the same lesson content were taught to both groups (experimental and control). Furthermore, the students in both groups (experimental and control) were taught in different schools.

iv. Controlling pre-test and post-test interaction effect: To control pre-test and post-test interaction effect, the items in the BTAT were reorganized before being used as post-test for the experimental and control groups. After the post-test, the items in the instrument were again re-organized before administering them as retention test for the experimental and control groups.

v. Use of Analysis of Covariance (ANCOVA) in Data Analysis: Analysis of Covariance (ANCOVA) was used to test the hypotheses in this study. This was done so as to check for the effect of non-randomization of the subjects.

\section{Results}

Differences in the mean achievement scores of students when taught Building Technology with edutainment instructional approach and when taught with the conventional lecture method

Table 1. Mean difference and standard deviation of students' pre-test and post-test scores in the building technology achievement test (BTAT) when taught with edutainment and lecture methods

\begin{tabular}{|c|c|c|c|c|c|c|c|}
\hline \multirow{2}{*}{\multicolumn{2}{|c|}{ S/NoTeaching Method }} & \multicolumn{3}{|c|}{ Pre-test } & \multicolumn{2}{|c|}{ Post test } & \multirow{2}{*}{$\begin{array}{l}\text { Mear } \\
\text { Gain }\end{array}$} \\
\hline & & $\mathrm{N}$ & $\bar{X}$ & S D & $\bar{X}$ & S D & \\
\hline 1 & Edutainment & 80 & 53.50 & 16.71 & 65.41 & 9.16 & 11.91 \\
\hline 2 & Lecture & 80 & 52.55 & 14.15 & 61.30 & 8.79 & 8.75 \\
\hline
\end{tabular}

Source: Researchers

Table 1 gives a summary results of the mean pre-test and post test scores of students in the experimental and control groups. The result shows that the mean pre-test and mean post-test scores of students in the experimental group who were taught with edutainment instructional approach are 53.50 and 65.41 respectively with standard deviation of 16.71 and 9.16 respectively. Table 1 also shows that the mean pre-test and mean post-test scores of students in the control group who were taught with the conventional lecture method are 52.55 and 61.30 respectively with standard deviation of 14.15 and 8.79 respectively. It could be observed that students in the experimental group had a higher mean gain of 11.91 as against 8.75 obtained by those in the control group. This result suggests that the edutainment instructional approach enhances students' academic achievement in Building Technology than the conventional lecture method. 
Table 2. Summary of analysis of covariance (ANCOVA) test for significant difference between students post-test scores in the building technology achievement test (BTAT) when taught with the edutainment instructional approach and conventional lecture method

\begin{tabular}{llllccc}
\hline Source & $\begin{array}{c}\text { Type III Sum } \\
\text { of Squares }\end{array}$ & df & \multicolumn{1}{c}{$\begin{array}{c}\text { Sean } \\
\text { Square }\end{array}$} & F & Sig. & Decision \\
\hline Corrected Model & 8060.16 & 2 & 4030.08 & 118.48 & 0.00 & \\
Intercept & 19832.55 & 1 & 19832.55 & 583.03 & 0.00 & \\
PRETEST & 7383.66 & 1 & 7383.66 & 217.06 & 0.00 & \\
GROUP & 545.04 & 1 & 545.04 & $* 16.02$ & 0.00 & S \\
Error & 5340.53 & 157 & 34.02 & & & \\
Total & 655643.00 & 160 & & & & \\
Corrected Total & 13400.69 & 159 & & & & \\
\hline
\end{tabular}

- $\quad \mathrm{S}=$ Significant at 0.05 level of Significance

The data in Table 2 shows the result of the analysis of covariance conducted to test for significant difference in the mean post test scores of students in the Building Technology Achievement Test (BTAT) between those taught with the edutainment instructional approach and those taught with the conventional lecture method with pre-test used as covariates. The students were divided into two groups by teaching methods namely edutainment and lecture methods. As shown, the F-value is 16.02 with level of significance being 0.00 . On this basis, the null hypothesis is rejected implying that there is significant difference in the post-test mean achievement scores in the Building Technology Achievement Test (BTAT) between students taught with the edutainment instructional approach and those taught with the conventional lecture method. The significant difference is attributed to the experimental group which obtained a higher mean post-test score in the BTAT.

Difference in the mean retention scores of Building Technology students taught with edutainment instructional approach and when they were taught with the conventional lecture method.

Table 3. Mean difference and standard deviation of students post-test and retentionscores in the buildingtechnology achievement test (BTAT) when taughtwith edutainment and lecture methods

\begin{tabular}{lllccccl}
\hline S/No & Teaching Method & \multicolumn{2}{c}{ Post-test } & \multicolumn{2}{c}{ Retention test } & Mean \\
& & $\mathrm{N}$ & $\bar{X}$ & $\mathrm{~S} \mathrm{D}$ & $\bar{X}$ & $\mathrm{~S} \mathrm{D}$ & Gain \\
\hline 1 & Edutainment & 80 & 65.41 & 9.16 & 72.03 & 5.89 & 6.62 \\
2 & Lecture & 80 & 61.30 & 8.79 & 63.03 & 5.72 & 1.73 \\
\hline
\end{tabular}

Source: Researchers

The result in Table 3 shows that the difference between the mean post-test and mean retention test scores of students in the experimental group who were taught with edutainment instructional approach is 6.62 while that of students in the control group who were taught with the conventional lecture method is 1.73 . It could be observed that students in the experimental group had a higher mean difference than those in the control group. This result suggests that the edutainment instructional approach enhanced students' retention in Building Technology than the conventional lecture method. 
Table 4. Summary of analysis of covariance (ANCOVA) test for significant difference between students retention scores in building technology when classified by treatment groups

\begin{tabular}{|c|c|c|c|c|c|c|}
\hline \multirow[t]{2}{*}{ Source } & \multicolumn{2}{|l|}{ Type III Sum } & \multicolumn{4}{|l|}{ Mean } \\
\hline & of Squares & $\mathrm{df}$ & Square & $\mathrm{F}$ & Sig. & Decision \\
\hline Corrected Model & 6380.79 & 2 & 3190.39 & 88.79 & 0.00 & \\
\hline Intercept & 37379.76 & 1 & 37379.76 & 1040.41 & 0.00 & \\
\hline PRETEST & 1715.19 & 1 & 1715.19 & 47.74 & 0.00 & \\
\hline GROUP & 4488.31 & 1 & 4488.31 & $* 124.93$ & 0.00 & S \\
\hline Error & 5640.71 & 157 & 35.93 & & & \\
\hline Total & 711624.00 & 160 & & & & \\
\hline Corrected Total & 12021.50 & 159 & & & & \\
\hline
\end{tabular}

\section{- $\quad \mathrm{S}=$ Significant at 0.05 level of Significance}

As shown in Table 4, the F-value for group (teaching method) is 124.93 with level of significance being 0.00 . This implies that the calculated value of $\mathrm{F}$ is significant at 0.05 level of significance. On this basis, the null hypothesis is rejected implying that there is significant difference between the mean retention scores of students taught Building Technology with the edutainment instructional approach and those taught with the conventional lecture method. The significant difference is attributed to the experimental group which obtained a higher mean score in the retention test.

\section{Discussion}

High performance of students in the experimental group could be attributed to the fact that the edutainment activities provide fun, excitement and motivation which arouse and sustain the students' interest in the topic being taught thus helping them to understand the lesson better than those in the control group. Also, the fun created by the teachers through the edutainment activities coupled with the active involvement of students in the lesson obviously enhance their critical thinking and problem-solving skills which considerably improved their academic achievement. Moreover, edutainment gives students the fundamental motivation for learning by providing enjoyment, passionate involvement, ego gratification, creativity, social interaction and emotion and these could enhance their learning.

The finding is in line with that of Udofia (2008) who found that students taught with edutainment instructional techniques obtained higher mean scores in Introductory Technology than those who were taught with the conventional discussion method. The finding of the present study also supports that of Adieze (2016) who, in a study on the comparative effects of edutainment, scaffolding and demonstration method on students' academic performance in Business Studies in secondary schools found that students who were taught with edutainment instructional approach performed better than those who were taught with the other two methods.

This result could be explained by the fact that students in the experimental group who were taught with edutainment instructional approach remembered more of what they learnt than those in the control group because of the multimedia video which made the lessons appealling to more than one of their senses. Specifically, the multimedia video which was incorporated into the edutainment instructional approach enable students to understand the lesson better since the lessons were presented using a combination of text, graphics, animation, pictures, video and sound. This provided opportunity for the students to use more than one sense organ to learn the concepts. In other words, the use of the multimedia videos appealed to the student's sense of sight while the background music and audio narration as well as the teacher's verbal explanations impacted on their sense of hearing. The combination of pictures and sound improved their retention of learning.

The finding of this study supports the views of Imogie (1998) cited in Ogwo and Oranu (2006) who stated that people use their sense organs for learning in the following proportion: $10 \%$ of what they read; $20 \%$ of what they hear; $30 \%$ of what they see; $50 \%$ of what they hear and see; $70 \%$ of what they say and $90 \%$ of what they say as they do a thing. The finding also supports the views of UNESCO (2003) who stated that videos are very beneficial in learning because it enhance students retention of the materials learnt for a longer time. The organization specified that the estimated amount of learning that occurs through the five senses is as follows: Taste $1 \%$, Touch $1.5 \%$, Smell $3.5 \%$, Hearing $11 \%$ and seeing $83 \%$. The organization also specified that after three hours, people retain $70 \%$ of material heard only, $72 \%$ of material seen only while they retain $85 \%$ of material that is both heard and seen. Other 
benefits of videos as identified by UNESCO (2003) which led to improved retention by the students include: videos add authenticity and reality to the learning context. It could help the students to visualize a process or see how something works, moves or how an activity is performed. Thirdly, real-life situations could best be presented and described using video as opposed to using text or audio. Videos could be used when "introducing a new theme to motivate and contextualize learning, after a topic has been addressed in a few class periods to aid students in applying the knowledge they acquired, or after an entire module is completed to show connections to other subjects and disciplines". Furthermore, the learner has the flexibility to replay, pause, and rewind videotapes and can repeat lessons as often as they wish. Videotape could also support the teaching of practical skills delivered through open and distance learning.

Furthermore, the finding of the study supports the assertion by Saleh, Prakash and Manton (2014) who posited that the most attractive and most significant advantage of edutainment is its ability to raise the students' motivation through the use of entertaining activities and multimedia tools which motivate and engage them in the learning material. The authors pointed out that teaching with entertainment is an effective way to transform complex and difficult topics to pleasant and attractive scenery. Also, edutainment help instructors to use creative tools instead of using the traditional chalk and board method. When teachers use these creative tools to teach, students could learn the materials more effectively.

\section{Recommendations}

Based on the findings of this study, the following recommendations are made:

1. Teachers of Building Technology in Akwa Ibom State Technical Colleges should adopt edutainment instructional approach for the teaching of Building Technology in order to enhance their students academic achievement and retention in Building Technology

2. The Akwa Ibom State Ministry of Education in collaboration with the state Technical Schools Board should recommend edutainment instructional approach for the teaching of Building Technology.

\section{References}

Abiola, L. L. (2014). The effect of digital story telling on kindergarten pupils' achievement in Moral instruction in Basic schools in Oyo state. Journal of Research and Methods in Education, 4(5), 26-34.

Adedoja, G. O., \& Fakokunde, J. B. (2015). Effect of computer-based instructional puzzle on students' learning outcomes and retention in Social studies. International Journal of Humanities and Social Science, 5(11), 181-188.

Adieze, C. (2016). Effects of edutainment, scaffolding instructional models and demonstration method on students' academic performance in Business Studies in secondary schools in Abia South Senatorial Zone in Abia State, Nigeria. International Journal of Educational Benchmark, 2(1), 72-84.

Berk, R. A. (2008). Use of technology and music to improve learning. Retrieved from www.ronberk.com

Betts, J. R., \& Shkolnik, J. L. (2000). The effects of ability grouping on studentAchievement and resource allocation in secondary schools. Economics of Education Review, 19(20), 1-15. Retrieved from www.elsevier.com/locate/econedurev

Boyle, S. (2011). Teaching tool kit: An introduction to games based learning. Retrieved from www.ucd.ie/teaching

Cohen, L., Manion, L., \& Morrison, K. (2011). Research Methods in Education (7th ed.). New York: Routledge.

Davies, W. (2013). What is edutainment and why is it important? Retrieved from www.humorcials.com/edutainment-defined

Eze, T. I., Ezenwafor, J. I., \& Obidile, I. J. (2016). Effects of problem-based teaching method on students' academic performance and retention in Financial Accountingin Technical colleges in Anambra State. Scholars Journal of Arts, Humanities and Social Sciences, 4(6A), 634-639. Retrieved from http://saspjournals.com/sjahss

Fatokun, K. V. F., Egya, S. O., \& Uzoechi, B. C. (2016). Effect of game instructional approach on chemistry students' achievement and retention in periodicity. European Journal of Research and Reflection in Educational Sciences, 4(7), 29-41.

Heiden, W. (2007). An edutainment approach to academic teaching. Retrieved from http://www.scholarworks.org

Hwa, S. P. (2009). Create an edutainment learning environment for mathematics learninginprimary schools. Proceedings of the 2nd International Conference ofTeaching and Learning (ICTL), INTI University College, 
Malaysia. Retrieved from www.attewell.org

Karen, A. M. (2015). Literature review: effectiveness of gaming in the classroom. Retrieved from www.amkaren.org/

Keshta, A. S., \& Al-Faleet, F. K. (2013). The effectiveness of using puzzles in developing tenth graders' vocabularly achievement and retention. Journal of Humanities and Social Sciences, 1(1), 46-57.

Kotluk, N., \& Kocakaya, S. (2017). The effects of creating digital storytelling onSecondary school students' academic achievement, self efficacy perceptions andattitudes towards physics. International Journal of Research in Education and Science, 3(1), 55-69.

National Business and Technical Examination Board (NABTEB). (2011). Chief examiners' report on the 2011 May/June NBC/NTC examinations. Benin City: Author.

National Business and Technical Examination Board (NABTEB). (2012a). Chief examiners' report on the 2012 May/June NBC/NTC examinations. Benin City: Author.

National Business and Technical Examination Board (NABTEB). (2012b). Chief examiners' report on the 2012 November/December NBC/NTC examinations. Benin City: Author.

Nworgu, B. G. (2015). Educational Research: Basic Issues and Methodology (3rd ed.). Nsukka.University Press Trust Publisher.

Odu, K. O. (2012). Reappraising the work skill requirements for building Technology education in senior secondary school for optimum performance in Nigeria. Proceedings of the 1st International Technology, Education and Environment Conference (c) African Society for Scientific Research (ASSR), 473-481.

Ogwo, B. A., \& Oranu, R. N. (2006). Methodology in Formal and Non-formal Technical and Vocational Education. Nsukka: University of Nigeria Press Ltd.

Oviawe, J. I. (2010). Differential effects of three instructional methods On students' performance in building technology In polytechnics in Nigeria. Unpublished Ph.D. Thesis, University of Nigeria, Nsukka.

Oviawe, J. I., Ezeji, S. C. O. A., \& Uwameiye, R. (2015). Comparative effects of three instructional methods on students' performance in building technology in Nigerian polytechnics. European Scientific Journal, 11(12), 274-286.

Oviawe, J. I., Ezeji, S. C. O. A., \& Uwameiye, R. (2016). Effectiveness of cooperative learning methods on Building Technology students' acquisition of work place skills. Indian Journal of Vocational Education, 20-21, 77-88.

Pakprod, N., \& Wannapiroon, P. (2015). Development of interactive instructional modelusing augmented reality based on edutainment to enhance emotional quotient. Retrieved from http://www.researchgate.net/publication/44636909

Saleh, N., Prakash, E., \& Manton, R. (2014). Factors affecting the acceptance of game-based learning. International Journal of Computer Applications, 92(13), 1-10.

Steffes, E. M., \& Duverger, P. (2012). Edutainment with videos and its positive effect onlong term memory. Journal for Advancement of Marketing Education, 20(1), 1-10.

Surjomo, H. D. (2015). The effect of multimedia and learning style on students achievement in online electronics course. Turkish Online Journal of Educational Technology, 14(1), 116-130.

Udoetuk, U. S. (2007). Effects of task instruction sheets on the achievement of Electricity/Electronics students in Colleges of Education in South-south Nigeria.Unpublished Ph.D. Thesis, University of Nigeria, Nsukka.

Udofia, G. A. (2008). Effects of edutainment on academic achievement and interest of students in Introductory Technology. Unpublished Ph.D. Thesis, University of Nigeria, Nsukka.

Umar, I. Y., Idris, A. M., Audu, R., Arah, A. S., Yusuf, E., \& Beji, A. A. (2015). Effects of multimedia instruction on students' academic achievement and retention in Auto mechanics at Technical Colleges. Global Journal of Education and Information Technology, 2(3), 1-11.

United Nations Educational, Scientific and Cultural Organisation and International Labour Organisation. (2003). Technical and vocational education system in the 25thcentury. Retrieved fromhttp://www.unesdoc.org

Usoro, A. D., \& Essien, E. E. (2012). Mechanism for Contending Over schooling among Students of Building/Wood Technology at Technical Colleges in Nigeria. American-Eurasian Journal of Scientific Research, 7(1), 41-46. 